\title{
Erratum to: Effect of follicle-stimulating hormone and testosterone on colony formation of bovine spermatogonial stem cell
}

P. Tajik • R. Narenji Sani • M. Moezifar • M. H. Yousefi • M. Movahedin • B. Qasemi-Panahi • Sh. Shafiei •

P. Rahimi Fili

Published online: 10 April 2013

(C) Springer-Verlag London 2013

\section{Erratum to: Comp Clin Pathol}

\section{DOI 10.1007/s00580-013-1710-z}

The original version of this article inadvertently contained a mistake. The affiliation address of B. Qasemi-Panahi was incorrect. It should be Department of Animal Science, Faculty of Agriculture, University of Tabriz, Tabriz, Iran.

The online version of the original article can be found at http:// dx.doi.org/10.1007/s00580-013-1710-z.

P. Tajik $\cdot$ R. N. Sani $(\bowtie) \cdot$ S. Shafiei $\cdot$ P. R. Fili Department of Theriogenology, Faculty of Veterinary

Medicine, University of Tehran, Tehran, Iran

e-mail: rezasani_vet@yahoo.com

\section{Moezifar}

Department of Basic Science, Faculty of Veterinary

Medicine, University of Tehran, Tehran, Iran

M. H. Yousefi

Faculty of Veterinary Medicine, Semnan University,

Semnan, Iran

M. Movahedin

Department of Anatomical Sciences,

School of Medical Sciences, Tarbiat Modarres

University, Tehran, Iran

B. Qasemi-Panahi

Department of Animal Science, Faculty of Agriculture,

University of Tabriz, Tabriz, Iran 